\title{
Iamblichus' Defence of Theurgy: Some Reflections
}

\author{
John Dillon \\ School of Classics, Trinity College, Dublin, Ireland \\ jmdillon@eircom.net
}

\begin{abstract}
An issue which plainly exercised the thoughts of many intellectuals in the late antique world was that of man's relation to the gods, and specifically the problems of the mode of interaction between the human and divine planes of existence. Once one accepted, as anyone with any philosophical training did, that God, or the gods, were not subject to passions, and that, as not only Stoics but also Platonists, at least after the time of Plotinus, believed, the world-order was (either entirely or very largely) determined as a product of God's providence, it became a serious problem as to how precisely one could influence the gods, or the course of events, by one's prayers or sacrifices. And yet efforts to do this, on both the popular and the official level, continued unabated. What was the proper attitude for a Platonist philosopher to take up? This is very much the subject of the well-known controversy between Plotinus' pupil Porphyry and his own pupil Iamblichus which manifests itself in the exchange of public letters known as The Letter to Anebo and The Reply of the Master Abammon to the Letter of Porphyry to Anebo (popularly known, since Marsilio Ficino conferred this title upon it, as De Mysteriis Aegyptiorum). The present article involves a close and sympathetic study of Iamblichus' position in defence of theurgy, reflecting on the validity of the distinction between religion and magic.
\end{abstract}

\section{Keywords}

theurgy, religion, magic, prayer, sacrifice, cosmic sympathy, Iamblichus, Porphyry

An issue which plainly exercised the thoughts of many intellectuals in the late antique world was that of man's relation to the gods, and specifically the problems of the mode of interaction between the human and divine planes of existence. Once one accepted, as anyone with any philosophical 
training did, that God, or the gods, were not subject to passions, and that, as not only Stoics but also Platonists, at least after the time of Plotinus, believed, the world-order was (either entirely or very largely) determined as a product of God's providence, it became a serious problem as to how precisely one could influence the gods, or the course of events, by one's prayers or sacrifices. And yet efforts to do this, on both the popular and the official level, continued unabated. What was the proper attitude for a Platonist philosopher to take up? ${ }^{1}$

This is very much the subject of the well-known controversy between Plotinus' pupil Porphyry and his own pupil Iamblichus which manifests itself in the exchange of public letters known as The Letter to Anebo and The Reply of the Master Abammon to the Letter of Porphyry to Anebo (popularly known, since Marsilio Ficino conferred this title upon it, as De Mysteriis Aegyptiorum). The Letter to Anebo is a comprehensive attack, through the medium of a series of innocent-sounding questions to an imaginary Egyptian priest, ${ }^{2}$ on a tendency which Porphyry plainly regards as profoundly subversive of both philosophy and religion. This tendency is that one which Sir James Frazer many years ago, in The Golden Bough (Vol. I, pp. 224-5), sought to make the basis for a distinction between religion and magic: religion seeks to please or propitiate a higher power, or powers; magic aspires, through the manipulation of natural forces, to dominate it or them, and bend them to the magician's will.

Since Frazer propounded this distinction, many scholars have sought to refine or even dissolve it. ${ }^{3}$ It is certainly reasonable to argue that the borders

\footnotetext{
1) On this general topic, see the most useful article of John Finamore 1999, which is largely complementary to the present essay; and of course the seminal study of Gregory Shaw, 1995, to which I am much indebted.

2) That is to say, very probably imaginary. It is, I suppose, possible, as some have suggested, that Anebo (whose name, unlike that of Abammon, is a validly-formed Egyptian one), was none other than the unnamed Egyptian priest who, Porphyry tells us in his Life of Plotinus (Ch. 10), performed a ceremony for Plotinus in the temple of Isis in Rome to conjure up his tutelary daemon (and succeeded in conjuring up a god instead). This incident occurred before Porphyry's arrival in Rome, but he might perhaps have chosen the man as a suitable addressee of such a letter. Even if so, however, it seems plain that this is an 'open letter' to the friends of theurgy within the Neoplatonic family, and that Iamblichus, who rather wittily assumes the persona of Anebo's superior in the priestly college, felt that it was at least partly directed at him.

3) A stimulating recent discussion, in the context of a study of prayer in the magical papyri,
} 
between religion and magic are a good deal fuzzier than Frazer wished to maintain, but it seems to me that there subsists nonetheless a clear opposition in theory between these two attitudes to the divine; and, more importantly, this was very much the view of Iamblichus. In fact, under pressure from Porphyry, Iamblichus seems to me, in the De Mysteriis, to stand forth as the first theorist of the distinction between religion and magicthough, as I shall argue, he is really taking a stand in defence of the 'higher' magic.

What I would like to do in this paper is to examine a series of key passages in the $D M$ in which Iamblichus asserts this opposition, in the process advancing his own theory of theurgy. First, however, let us consider those questions of Porphyry which provoked Iamblichus into taking up the positions that he does. Iamblichus himself summarizes Porphyry's points before countering them, but it is perhaps more convenient to present them in the summary account given by St. Augustine in his City of God (X 11). Augustine speaks of Porphyry as (deviously) 'likening himself to an enquirer in search of advice (consulenti similis et quaerenti), for the purpose of exposing and overturning these sacrilegious arts,' and that is certainly the format that emerges from Iamblichus' replies to him. I quote a number of the chief queries that he raises:

Moreover, he expresses surprise that gods are not only enticed by victims, but are even actually compelled and forced to do the will of men (compellantur atque cogantur facere quod homines volunt); and if gods are distinguished from daemons by being bodiless, while daemons have bodies, he wonders how we can believe that the sun and moon and the other objects visible in the sky are gods, for he has no doubt that they are bodies; and, if they are gods, how some are classed as beneficent and others as maleficent, and, since they are material bodies, how they are bound to immaterial beings.

Between them, these queries go to the root of the philosophical objections to magic and astrology. Iamblichus responds to them vigorously during the course of Book I. ${ }^{4}$ He begins (Chs. 4-7) by asserting that, though we

is that of Fritz Graf 1991. Magical prayer is certainly a somewhat confused and confusing activity; the attitude to the deity addressed often seems to change almost from sentence to sentence, between petition and command.

4) Iamblichus in fact comes out with fists flailing, not conceding Porphyry an inch of 
should recognise fully four classes of 'superior being', the two 'extremes' of gods and pure souls, and the two 'means' of daemons and heroes, none of these is such as to have a nature that is bound to, or dependent upon, what is below it - that is, the material world. Gods are totally transcendent and free from contact with the material world; incorporeal souls, on the other hand, do 'incline towards' the bodily, but even so they are not contaminated or constrained:

Further, to the one (sc. the gods) there pertains what is highest and most incomprehensible, superior to all measure, and formless ( $\dot{\alpha} v \varepsilon i ́ \delta \varepsilon o v)$ in the sense of being unbounded by any form, while the other (sc. the class of souls)

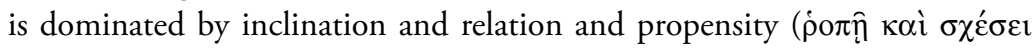

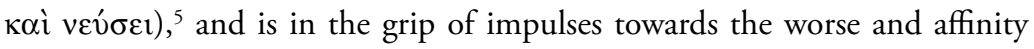
with things secondary, and consequently informed in multifarious ways by the measures deriving from them. So then Intellect (vov̂s), as leader and king in the realm of Being, ${ }^{6}$ and the art which creates the universe ( $\tau \dot{\varepsilon} \chi \vee \eta$

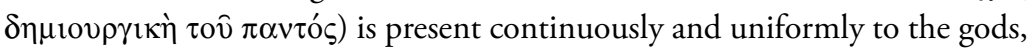
perfectly and self-sufficiently and free from any deficiency, established in itself purely and in accordance with one sole activity, while the soul participates in a partial and multiform intellect, ${ }^{7}$ which has its attention directed to the government of the universe, and itself has care for the inanimate realm, being

\footnotetext{
ground. He even challenges Porphyry's opening remark (reported in DM I 3 ) that he 'con-

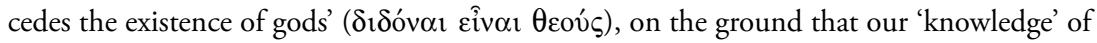
their existence "is superior to all judgement and choice, reasoning and proof... Indeed, the contact ( $\sigma v v \alpha \varphi \eta$ ) we have with the divinity is not even to be taken as knowledge." There is a certain amount of 'oneupmanship' in this, designed to wrong-foot Porphyry, but he is also making an interesting point about the basic and innate nature of our apprehension of the existence of God.

5) All good Neoplatonic terms for the relation to what is below; cf., for porn', Iambl. In Phd. Fr. 5 Dillon; In Tim. Fr. 16; for $\sigma \chi \varepsilon \dot{\sigma} \sigma \varsigma$, Procl. In Remp. I 207, 18ff.; II 310, $1 \mathrm{ff.;}$ In Tim. I 115, 25; I 141, 16; for vev́бıs, Iambl. In Tim. Fr. 40, 4 Dillon; Procl. In Tim. 1, 52, 23; III 258, 19.

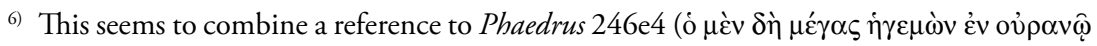

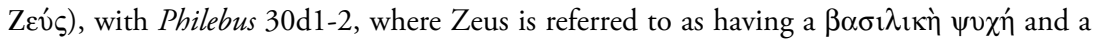

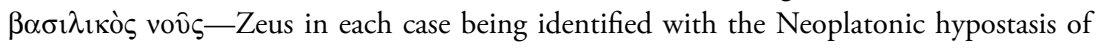
Intellect.

7) In terms of Iamblichean metaphysics, this would refer to the lowest element in the intelligible realm, the 'participated Intellect' ( $\mu \varepsilon \theta \varepsilon \kappa \tau$ òs vov̂ऽ), which is the aspect of Intellect with which Soul immediately communicates; cf. In Tim. Frs. 55 and 56 Dillon.
} 


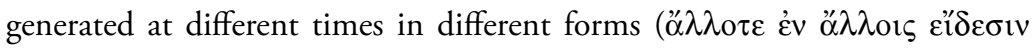

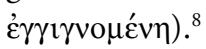

Iamblichus does, then, admit that Soul, as the lowest element in the intelligible world, is essentially concerned with the physical world, but even so, not in such a way as to be controlled or contaminated by it. Prayers and sacrifices, in any case, are not directed to souls, but to higher levels of being. The gods themselves, he would maintain, but also the daemons and heroes, are quite free of any material contamination or passibility (I 8).

On what terms, then, may contact with them be made? The issue of the compulsion of gods, and of the apparent treatment of them as if they were subject to passions or external influences generally, is addressed in chs. 11-14 of Book I. Let us look at a few key passages.

First, the beginning of ch. 11 (37):

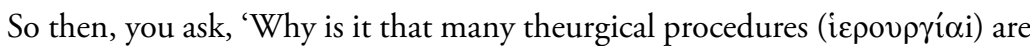
directed towards them as if they were subject to passions ('غ $\mu \pi \alpha \theta \varepsilon i \varsigma)$ ?' Well, my reply to this is that the question is asked out of an inexperience of sacred

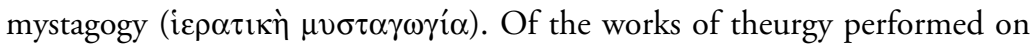
any given occasion, some have a cause that is secret and superior to all rational explanation, others are like symbols $(\sigma \hat{\prime} \mu \beta \mathrm{o} \lambda \alpha)$ consecrated from all eternity

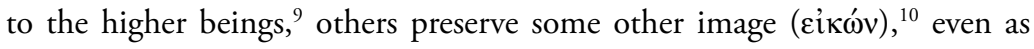
nature in its generative role imprints (upon things) visible shapes from invisible reason-principles; others yet are performed in honour of their subjects, or have as their aim some sort of assimilation $\left(\dot{\alpha} \varphi \mu_{\mu o i ́} \omega \sigma \iota\right)$ or establishment of

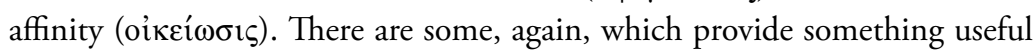
for us, or in some way or other purify and dissolve our human passions, or ward off some other of the dangers that menace us. One would not, however, for all that agree that some part of our ritual is directed towards the gods or

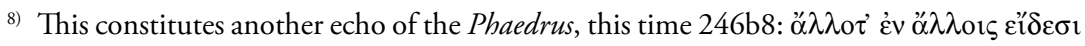
$\gamma(\gamma v o \mu \varepsilon ́ v \eta$, referring to the manner in which Soul administers the whole cosmos.

9) This would mean, of course, that they are sown in nature by the gods themselves, and therefore cannot involve external compulsion upon the gods, but rather the activation of benign influences emanating from them.

10) The distinction here made between symbolon and eikôn may be mere literary variation, but it may reflect the distinction sometimes made in the Neoplatonic tradition between the two terms, and referred back by Proclus (In Tim. I 29, 31ff. Diehl) to the 'Pythagoreans', a reference for which he seems to be indebted to Iamblichus.
} 
daemons which are the subjects of our cult as subject to passions; for that essence which is of itself eternal and incorporeal cannot itself admit any alteration emanating from bodies.

So much for that, then. Theurgic practices may appear coercive of the gods, but that is only to the untrained, superficial eye. What the theurgist is really doing is, instead, tuning in to the gods, getting onto their wavelength, by utilizing the symbola that they themselves have sown in the cosmos. He may use many of the invocations, including voces magicae, and many of the materials, of the 'vulgar' magicians, but he is using them with a proper understanding of how they work.

Iamblichus continues, in Ch. 12, to emphasize that, contrary to appearances, it is solely by the gods' own benign will that they respond to the theurgists' appeals: "It is by virtue of such will, then, that the gods in their benevolence and graciousness unstintingly shed their light upon theurgists, summoning up their souls to themselves and orchestrating their union with them, accustoming them, even while still in the body, to detach themselves from their bodies, and to turn themselves towards their eternal and intelligible first principle." In fact, by the practice of the appropriate rites, the theurgist rises above the human plane of existence, and joins himself to that of the gods. ${ }^{11}$

A little further on, in Ch. 14, he addresses directly the question of $\theta \varepsilon \hat{\omega} v$

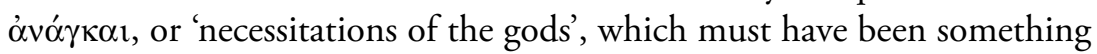
of a catch-phrase among either magicians, or opponents of magic, or both, which Porphyry had plainly made allusion to. ${ }^{12}$ Iamblichus boldly turns this phrase on its head $(44,11 \mathrm{ff}$.), interpreting the objective genitive as a subjective genitive:

Furthermore, the so-called 'necessities of the gods' are just that, necessities of the gods,$^{13}$ and come about in accordance with the nature of the gods. It is not, then, as from an outside source or by force, but as their good would have it of

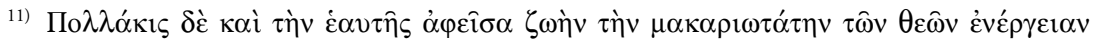
$\dot{\alpha} v \tau \eta \lambda \lambda \alpha^{\prime} \xi \alpha \tau o(41,16-18)$.

12) This is confirmed by Augustine's summary (X 11, 418, 27-9 Dombart-Kalb): miratur (sc. Porphyrius) autem quod non solum dii alliciantur victimis, sed etiam compellantur atque cogantur facere quod homines volunt.

13) Sc. directed by the gods, not imposed on them.
} 
necessity, that they are always so disposed, and never inclined otherwise. Such a necessity as this, then, is mingled with a benign will and is a friend of love

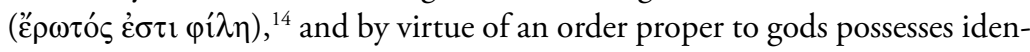
tity and unchangeability, and because it is, according to the same terms and conditions, held within a single limit, it remains within it and does not step outside of it. So, for all these reasons, there results the contrary of your conclusions; the consequence is that the divine is exempt from external bewitchment or affection or constraint, if in truth the powers inherent in theurgy are real, and such as we have demonstrated them to be.

We may turn now to the central issues of prayer and sacrifice, as being those in which the spheres of religion and magic come closest together, and, by the same token, require to be most firmly distinguished. First, a response to another troublesome challenge from Porphyry, in the next chapter of Book I (47, 12ff.):

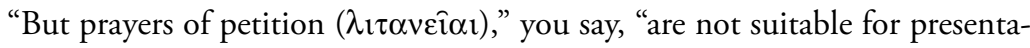
tion to the purity of the Intellect." ${ }^{15}$ Not so; for by reason of this very circumstance, that we are inferior to the gods in power and in purity and in all other respects, it is eminently suitable that we entreat them to the greatest degree possible. The consciousness of our own nothingness, if one judges it in comparison with the gods, makes us naturally turn to supplications; and by the practice of supplication we are raised gradually to the level of the object of our supplication, and we gain likeness to it by virtue of our constant consorting with it, and, starting from our own imperfection, we gradually take on the perfection of the divine.

This passage initially strikes a note of truly Christian humility, but we can observe a subtle change of emphasis from the assertion of our nothingness

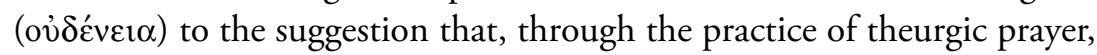

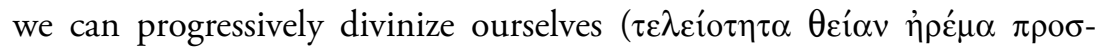
$\left.\lambda \alpha \mu \beta \alpha \alpha^{\prime} \nu \mu \varepsilon v\right)$. What follows reinforces this impression (48, 5ff.):

And if one were to consider also how the hieratic prayer-formulae ( $\alpha i$

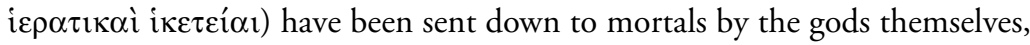

\footnotetext{
14) The meaning of this rather odd phrase presumably is that the anagkê of the gods is near akin to love.

15) That is to say, Nous as the ruling principle of the intelligible world.
} 
and that they are tokens $(\sigma v v \theta \eta \dot{\eta} \mu \alpha \alpha)^{16}$ deriving from the gods themselves, how could one any longer justly believe that such supplication is derived from the sense-world, and is not divine and intellectual? Or how could any element of passion be reasonably insinuated into this activity, seeing that not even a virtuous human character can easily be brought to the requisite level of purity? ${ }^{17}$

It is the gods themselves who have supplied the synthêmata of which the theurgist makes use, so that the use of them must ipso facto be pleasing to the gods, and any positive results from them not a consequence of any compulsion, but of their benevolence. ${ }^{18}$

It is this expertise in the utilizing of the clues which the gods have sown through the universe which sets the theurgist apart from, and above, the theoretical philosopher. Iamblichus presents a rather well-known statement of the distinction in Book II, Ch. 11 (96-7): ${ }^{19}$

It is not thought ( $\left.\varepsilon^{\prime} v v_{01 \alpha}\right)$ that links the theurgists to the gods: otherwise, what would prevent theoretical philosophers from enjoying theurgic union with them? In fact, the truth is quite otherwise: theurgic union is brought about only by the perfective operation of ineffable acts correctly performed, acts which are beyond all understanding, and by the power of the unutterable symbols which are intelligible only to the gods. ${ }^{20}$ For this reason it is not by intelligizing that we successfully perform these acts; for in that case their actualization would be an intellectual process and contributed by us. But neither

\footnotetext{
16) In the Chaldaean sense of 'clues' or 'traces' sown by the gods in physical cosmos. These would comprise, or at least include, voces magicae and other meaningless utterances. Cf. the discussion of magical names at VII 4-5.

17) That is to say—and it is a point often reiterated by Iamblichus (cf. II 11, 96-7)—not even the most accomplished sage, so long as he maintains a purely intellectual approach (as does Porphyry, and as did Plotinus before him), can attain to the highest levels of theurgic union.

18) A simple analogy from the Christian tradition would be the Lord's Prayer, which would derive its efficacity from the fact that it was dictated by Christ himself. It does not, however, have the additional virtue of meaninglessness.

19) Quoted, rather disapprovingly, by E.R. Dodds, in the Introduction to his edition of Proclus: The Elements of Theology (Oxford, 1963, p. xx).

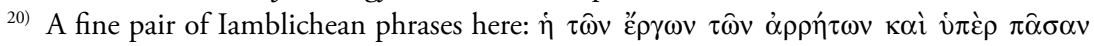

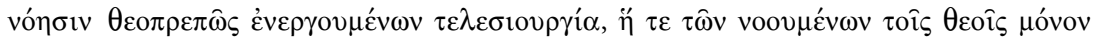

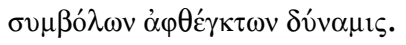


of these propositions is true. For in fact the actual tokens ( $\sigma v v \theta \dot{\eta} \mu \alpha \tau \alpha)$ of themselves perform their proper function even without our conscious thought ${ }^{21}$ and the ineffable power of the gods, towards whom these things draw us up, of itself recognizes its own images, but not by being summoned up by our intellectual activity (vónбıs).

These 'acts' (erga) will be, inevitably, sacrificial activities very little different, in their external manifestations (e.g. gathering and mingling of sacred substances, sacrifice of a sanctified animal of some sort, and the utterance of prayers involving voces magicae), ${ }^{22}$ but of course informed through and through by the higher conceptions which the theurgist brings to bear.

It is in Book V, however, that Iamblichus focuses particularly on the topic of sacrifice. Porphyry provokes the content of Book $\mathrm{V}$ by a question which St. Augustine summarizes as follows (City of God X 11): "Why do they (sc. the gods) insist that their priests abstain from eating meat, no doubt to guard themselves from the danger of pollutions by their bodily exhalations, while they themselves are attracted by smells, and especially by the stench of sacrificial victims?" This challenges more or less all the assumptions that Iamblichus is making, and he meets it head on (V 1, 199):

The question that you raise next is one that is a common concern for virtually all men, both those who have given time to cultural pursuits and those relatively lacking in experience of philosophical argument, I mean the question of sacrifices: what is the utility of them, or what power do they have in the universe or with the gods, and on what principle do they achieve their purpose, both appropriately to those being honoured, and usefully for those presenting the gifts?

\footnotetext{
21) It is, I believe, a feature of Christian sacramental theology to maintain that sacraments, correctly performed, do their work quite independently of the state of mind of the priestly celebrant, provided only that the celebrant concerned is properly qualified. If so, Iamblichus' doctrine enunciated here may have had some, albeit unacknowledged, influence in that quarter.

22) As a nice example, I adduce a procedure (PGM III 1-164) which it fell to me to translate, some time ago, for the Chicago translation of the Papyri Graecae Magicae (Betz, 1986, pp. 18-22), involving the drowning of a cat in a tub of water, the assembling and employment of various substances, such as cinnabar and storax gum, and the utterance of invocations - though here the tone is quite alien to the theurgical pretensions of Iamblichus, being of a distinctly minatory and imperious nature.
} 
The gods, after all, as has been made clear many times already, are totally transcendent over matter, and not subject to passion of any kind. Even the celestial gods, bound though they are to bodies of a sort, are not constrained by those bodies (presiding over them effortlessly, as they do) in such as a way as to be subject to any outside influence, and certainly not to exhalations from the sublunary sphere $(\mathrm{V} 4)$. The same, he maintains, is true also of daemons (V 10: 211).

How, then, do sacrifices work-since Iamblichus is adamant that they do? We find a good statement of the rationale in c. $9(209-210)::^{23}$

It is better, then, to seek the cause (sc. of the efficacy of sacrifices) in kinship

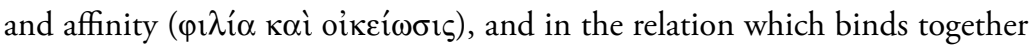
creators with their creations and generators with their offspring. When, therefore, under the guidance of this common principle, we comprehend that some animal or plant growing in the earth simply and purely preserves the intention of its maker, then, through this intermediary, we set in motion, in an appropriate manner, the creative cause which, without in any way compromising its purity, presides over this entity.

Since these causal relationships are numerous, and some have an immediate source, as in the case of daemonic ones, while others are superior to these, having divine causes, and, higher than these again, there is the one preeminent Cause, ${ }^{24}$ all these levels of cause are activated by the performance of perfect sacrifice; each level of cause is related to the sacrifice in accordance with the rank to which it has been allotted.

So sacrifices work, not by putting any constraint on the gods, or by providing them with anything which they enjoy or need, but simply by activating those elements in the physical universe which possess a natural relationship of oikeiôsis with higher powers. If one can do that, the gods will come, of their own benevolent free will.

Here Iamblichus, it seems to me, while striving to free theurgy from any imputation of attempting to manipulate the gods, rather gives the game away. Sir James Frazer's distinction between magic and religion is, after all,

\footnotetext{
23) Beate Nasemann (1991) gives a useful analysis of this passage in her monograph Theurgie und Philosophie in Jamblichs De Mysteriis, Stuttgard, 1991, pp. 123-145.

24) Presumably a covert reference here to the Neoplatonic One.
} 
basically valid, and Iamblichean theurgy is firmly established on the magical side of the divide. This is not, however, necessarily a criticism or condemnation of him. Emma Clarke, in a recent monograph ${ }^{25}$ utters a salutary caution against trying, in our efforts to "rehabilitate" Iamblichus as a philosopher, to free him from all imputation of what would appear to modern sensibilities as "irrationality." Iamblichus would not at all appreciate being so freed. Unlike a purely "religious" philosopher, he is firmly of the belief that ritual, which he sees as the expert manipulation of the multiplicity of substances which the gods themselves have sown into the world as synthêmata, and which they are perfectly happy for the theurgist to discover, is essential for attaining union with gods, as well as power over the natural world. ${ }^{26}$

The distinction commonly made between magic and theurgy is in fact, in my view, basically an unreal one. The real distinction is between magicl theurgy — and its remote descendant, the modern scientific world-view-, and religion. Behind the latter is the impulse to abase oneself before some force alien to oneself that is infinitely powerful and mysterious; behind the former is the impulse to come to terms with that force, and the physical world it has created, to ferret out what makes it tick, and to manipulate it for one's own ends. These are two very different impulses in man. Of the two, Iamblichus is firmly in the former camp, and in the De Mysteriis he has indeed provided a manifesto for this attitude to the world. I would go so far as to suggest that theurgy is really no more than magic with a "rational account," or logos, to back it up. The vulgar magician knows, perhaps, what is to be done to achieve a certain, usually rather trivial, result; the theurgist knows in addition why such procedures are to be followed, and how they really work. He does not flatter himself that he is in any way superior to divinities (except perhaps, stretching a point, to little local daemons), and he will avoid any suggestion of arrogance when addressing his superiors, but deep down he knows this great truth: that if he presses the right buttons, they will come. And that is the basis of his difference with, and (in his own mind) superiority to, Porphyry and the "religious" philosophical tradition.

\footnotetext{
25) Clarke (2001).

26) For a good discussion of the points here briefly made, see Shaw (1995), esp. Sect. III: 'The Liturgy of the Cosmos'.
} 


\section{Bibliography}

Betz, H.D. (ed.) 1986. The Greek Magical Papyri in Translation. Chicago: University of Chicago Press.

Clarke, E.C. 2001. Iamblichus' De Mysteriis: A Manifesto of the Miraculous. Aldershot: Ashgate.

Clarke, E.C., J.M. Dillon and J. Hershbell. 2004. On the Mysteries of the Egyptians: The Reply of the Master Abamon to the Letter of Porphyry to Anebo, text, translation and notes. Atlanta: Scholars Press/Leiden: Brill.

Des Places, E. 1966. Les mystères d'Egypte, text and French translation. Paris: Presses Universitaires de France.

Dodds, E.R. 1963. Proclus' Elements of Theology, 2nd ed. Oxford:

Finamore, J. 1999. 'Plotinus and Iamblichus on Magic and Theurgy'. Dionysius 17, 83-94.

Graf, F. 1991. 'Prayer in Magical and Religious Ritual', in C.A. Faraone and D. Obbink (eds.), Magika Hiera: Ancient Greek Magic and Religion. Oxford: Oxford University Press, 188-213.

Nasemann, B. 1991. Theurgie und Philosophie in Jamblichs De Mysteriis. Stuttgart: Teubner.

Shaw, G. 1995. Theurgy and the Soul; the Neoplatonism of Iamblichus. University Park, PA: University of Pennsylvania Press. 